\title{
THE MODEL OF PRAXEOLOGICAL COMPETENCE FORMATION IN FUTURE MASTERS OF DENTISTRY
}

\section{Skrypnyk, Ya. Kulbashna}

The article elucidates the significance of future dentists' practical training. It has been established, that the great attention of available foreign scientific sources is paid to the issue of improving the dental educational content based on the competence approach; nevertheless, modeling of educational process' components has not been considered so far.

The importance of modeling, as a method of educational process' studying components, has been determined. The authors' model of praxeological competence formation of future master of dentistry is presented. It consists of the basic components, which are determined as interconnected blocks: the target one declares the goal and defines the tasks necessary for its achievement; theoretical-methodological block reveals the praxeological competence structure (motivation, gnostic, activity, deontic, scientific-research, reflexive components), basic approaches (competence, system, personal, activity, synergetic, context), principles (subsequence, transparency, evidence-based, scientificity, rationality, creativity, effectiveness) and ways for achieving the aim based on the updated normative base of dental education (branch educational standard of the specialty "Dentistry", EQC, EPP, elaborated on its base and with the use of necessary pedagogical conditions); the content-procedural block determines the ways of pedagogical conditions realization based on the updated content of dental education of interdisciplinary integration of basic and professional subjects, improvement of methodological instruments (classroom work, projects, self-study work, individual, distant forms; traditional, innovative, interactive methods; means of simulation, under clinic conditions, portfolio), resulting-reflexive block reflects and fixes the levels of future masters' of dentistry praxeological competence formation according to its components and is based on correspondent criteria and indicators, gives a possibility to ascertain an obtained educational result according to defined levels (minimal and sufficient).

The model shows the researched process as an integral system that gives a possibility to correct the future masters' of dentistry professional training according to the influence of internal and external factors on the educational process; to determine vectors of its evolution in the context of competence approach introduction into dental education

Keywords: dental education, professional competence, model, praxeological competence formation

Copyright (C) 2021, I. Skrypnyk, Ya. Kulbashna.

This is an open access article under the CC BY license (http://creativecommons.org/licenses/by/4.0).

\section{Introduction}

Practical training of dentists is in the spotlight of the European educational space. It is systematically researched in all relevant aspects, especially in the context of a competence educational paradigm $[1,2]$. The importance of the practical component of the future dentists' professional training as an indicator of their readiness to the professional activity and competitiveness is constantly growing in the process of Ukrainian educational environment integration to the European one. This situation requires permanent improvement of theoretical and methodological bases of its quality provision at medical universities [3]. Achieving this aim in the context of competence approach introduction in higher education provides praxeological competence formation (further$\operatorname{PrC})$ of a graduate [4].

According to scientists $[5,6]$, one of methods of influence on the educational process at a higher school for raising the effectiveness is its components modeling. They indicate that the essence of the method is in projecting and schematic presentation of the studied object as an integral system - from setting an aim to obtaining a desirable outcome that gives a possibility to determine its basic components (blocks), to discover subsystems and to establish their interconnec- tions in the context of a competence educational paradigm. Such method becomes actualized more and more in medical education $[7,8]$.

Modeling of the formation process of praxeological competence of future masters of dentistry (further PrCFDM) is based on modern scientific approaches, it is necessary for determining main interrelations of the educational process in the context of dynamic development of the professional training practical component. It gives a possibility to establish their interconnections, needs in modernization, concretization, detailing and integration for orientation on future clinical activity, to search for new effective means for solving set professional tasks using innovative pedagogical technologies, context learning, timely renewal of the content by introducing substantiated changes to normative acts, regulating the educational process at medical universities, syllabi, forms and means.

Modeling variants for different components of the educational process at a medical university and professional training of future medical personnel are presented in not numerous researches of scientists, but only few of them [7, 8] partially consider the problem of future dentist professional training that actualizes this research. 


\section{Literary review}

Integration of Ukrainian higher education, especially medical one, to the European educational space is defined as one of basic tasks of its development [9]. It actualizes studying of the progressive international experience of educational process functioning, especially in the context of a competence educational paradigm.

Specialists of dental education in the EU are conducting substantiated researches for improving its quality [10]. Thus, the global project was introducing for 9 years in the EU countries [11], within which basic approaches and requirements to the training of a competent dentist were revealed, especially, the mutual conditionality of the notions "competence" and "educational result" was analyzed. The essential covering of their competences and significant regional variability of interpretation were established. After reclassification and specification, original domains of competences were simplified that maximally corresponded to modern approaches in dental education. As a result, the number of basic competences, preliminarily defined for a graduate-dentist, was decreased from 7 [12] to 4 [1], where 2 of them relate to students' practical training directly and may be considered in the context of future dentist's praxeological competence formation, particularly: Safe and Effective Clinical Practice that includes such subordinated competences: Evidence-Based Practice; Management and Leadership; Team-working and Communication; Audit and Risk Management; Professional Education and Training and Patient-Centered Care that Applying the Scientific Basis of Oral Health Care; Clinical Information Gathering and Diagnosis; Treatment Planning; Establishing and Maintaining Oral Health.

We have not revealed the data about modeling as a method of research the educational process of training a competent dentist in available foreign sources, but it was considered by scientists in other aspects that especially concern modeling of a doctor's personality on a teacher's example [13].

The notions "model" and "modeling" as a research method in pedagogy are borrowed from other scientific branches $[14,15]$. They are widely interpreted in both reference sources and works by modern scientists. Modeling in higher education becomes an unalienable part of pedagogical studies, because according to scientists' definitions $[14,16]$, - it is a method of materialization of an idea of an integral system, reflecting a research subject, which is able to give updated information about an object, favors its dynamic changes and solving of important tasks on optimization of the learning material structure, improvement of such educational process aspects as planning, guiding, diagnostics, prognostication and correction of cognitive activity of future specialists. As N. Boyarchuk states [14] models transmit an information essence of an object, open its versatility, and the modeling method - provides elaboration of hypothetic mutually connected structural elements. At the same time O. Mikheenko [16] considers model as a means of simplified image/scheme of any object, process or phenomenon and opens a possibility of transferring information from a model to a prototype. A model is an intermediate link between advanced theoretical propositions and their verification in the real pedagogical process according to S. Vitvitska [15].

The experience of N. Demjanenko [17] on elaboration of a context - professional model of future specialists' competence formation that may be universal for ones of different branches is beneficial for our study. The scientist proposes to introduce organizational changes with elements of quaziprofessional activity, interdisciplinary integration, mixed learning in universities.

The aim of developing a model of PrCFDM formation is a schematic reproduction, structuration of the research object - practical component of the dentistry master's professional training, reflecting conceptual connections between components (notion, conceptual, procedural) in the process of PrCFDM formation that discovers connections establishment between them according to the aim and tasks and they facilitate the aim achievement, taking into account professional activity peculiarities. To achieve the goal, it is necessary to realize the tasks: to represent the integral educational process of praxeological competence formation of future masters of dentistry taking into account modern approaches to professional training, directed on mastering necessary competences, knowledge, skills, creating pedagogical conditions, observing basic principles in attaining the set aim, assessing the educational result.

At developing the model of PrCFDM formation it is necessary to observe correspondent principles. We agree with an idea of scientists [7] that it is necessary for modeling the process future specialist' competence formation to observe the structural-functional correspondence between the model and the modeled object; concreteness; subordination to the aim; hierarchic coordination; actual realization; functional-logic structuration; systemacity; conceptual correspondence; information adequacy.

\section{Research aim and tasks}

The aim of the paper is to substantiate theoretically the structural-functional model of future masters' of dentistry praxeological competence formation.

The modeling object is a practical component of future masters' of dentistry professional training, testifying to the graduates' readiness to practical activity realization, integrated with its other components.

The following tasks were set for achieving this aim:

1. To present the educational process of future masters' of dentistry praxeological competence formation as an integral system.

2. To determine interconnections of structural elements of the model.

\section{Materials and methods}

For developing the model of PrCFDM formation, the following methods were used: analysis of information from scientific sources, its generalization, analysis of own pedagogical experience, modeling of PrCFDM formation process.

\section{Results}

Main theoretical studies of the issue of future masters' of dentistry praxeological competence formation (PrCFDM) that became a base for creating the 
model of the studied process (then - model) were elucidated in works [3, 4, 18, 19], published earlier. They disclose the essence of the notion "PrCFDM", determine the importance of methodological instruments, develop the structure, base principles, necessary to observe in the process of its formation. The model (Fig. 1) consists of several mutually connected structural blocks, reflecting the integrity of main studied aspects of the learning process. The first of them is target one which declares the goal of future masters' of dentistry praxeological competence formation and defines the tasks necessary to realize for its achievement - formation of the components of the dentistry master's PrC - motivation, gnostic, activity, deontic, scientific-research, reflexive one.

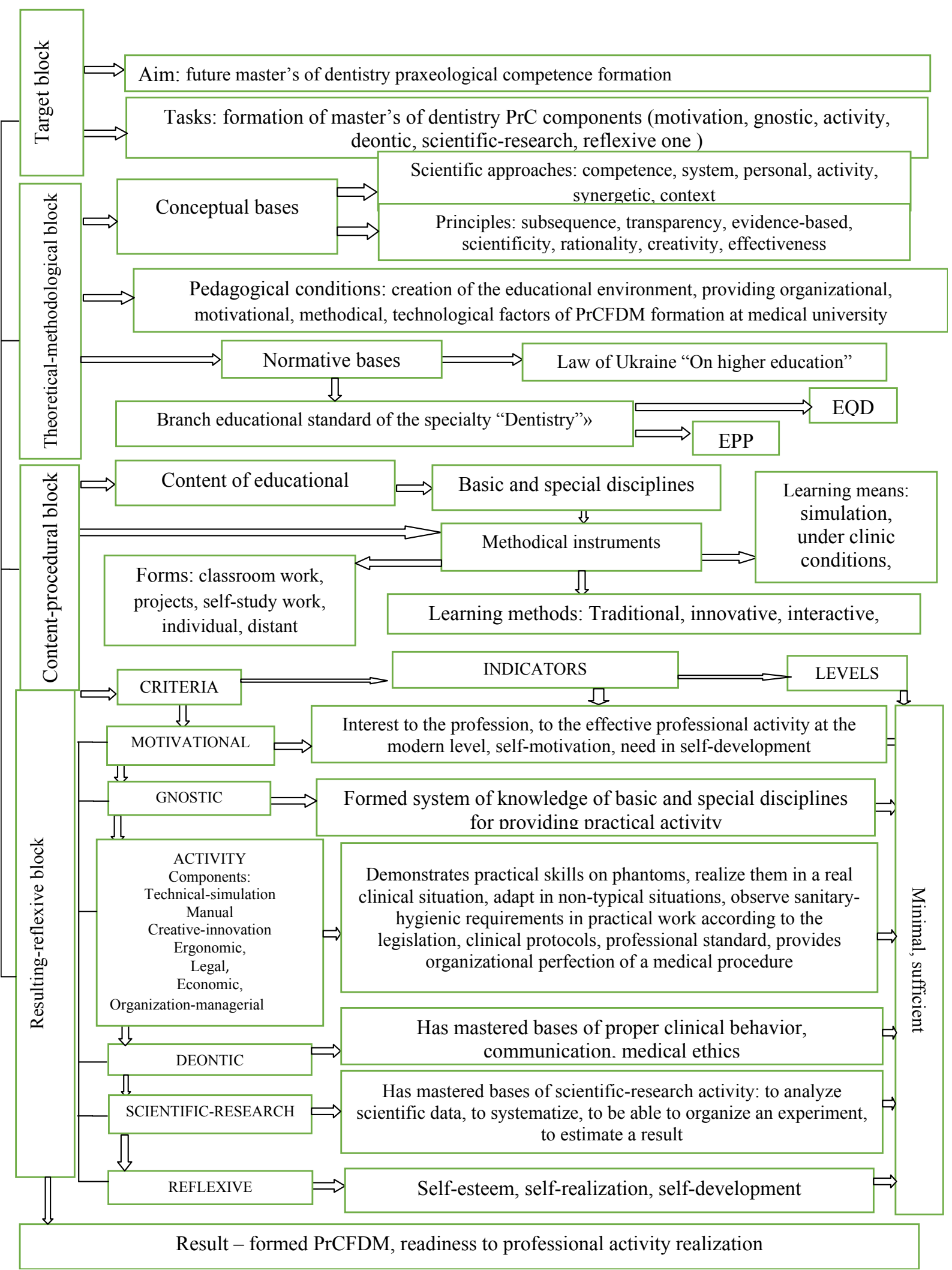

Fig. 1. Model of future master's of dentistry praxeological competence formation 
The second, theoretical-methodological block discovers the praxeological competence structure in the totality of its components (motivation, gnostic, activity, deontic, scientific-research, reflexive), characterizes basic approaches and the ways of aim achievement based on the updated normative base of dental education branch educational standard of the specialty "Dentistry" [20], EQD (educational qualification description), EPP (educational professional program), elaborated on its base; modern scientific approaches (competence, system, personal, activity, synergetic, context) and principles (subsequence, transparency, evidence-based, scientificity, rationality, creativity, effectiveness) that conceptual support of the educational process is based on. briefly characterize main scientific approaches, base in PrCFDM formation:

- System approach, providing the integrity and continuousness of the educational process, creating a system of components that are mutually interconnected and undergo an influence, determined by the aim, content, forms and methods [21]. It orient subjects on the activity, providing praxeological competence formation, unites structural components of the model in the integral totality, taking into account peculiarities of the professional training of future masters of dentistry;

- personally oriented approach is one of determining approaches for the educational process at a medical university, because it actualizes the individual approach to each student, development of learner's ability to think creatively and critically, to find solutions in nontypical professional situations [22]. At the same time, doctor's work provides communication with different contingents of persons (patients, their relatives, associated medical staff and so on) [23] and effective cooperation of all parties of the pedagogical process for guaranteeing comprehensive creative development of a personality of future doctors;

- activity approach. The statement by I. Melnichuk [24] about the essence of the activity approach in the context of training future medical specialists is worth attention. The scientist mentions that a person becomes a subject of cognition and transformation of objective reality only due to activity. It student's perception of knowledge as conscious convictions, becoming a means for a correspondent actions, considers different types of professional activity, realized for attaining a desirable outcome, expressed in attaining the maximally professional way of action. The activity approach in the formation process of the PrCFDM model is realized by integration of different types of activity in the educational process of future doctors, especially practical activities in phantom classes and clinic conditions, production practice, communication with colleagues, medical staff, patients, experience of simulation learning technologies, work with modern computer programs and so on;

- competence approach provides realization of acquired knowledge, abilities and skills in the professional activity and their transformation in correspondent competences, using for that learning content, methods, means, forms and technologies, modernized according to today educational standards. Competence-oriented knowledge as an important factor of future specialists' professional competence formation [25], especially praxeological competence that is just an organic component of the dentist's one, gets special significance [7];

- context approach encourages the professional training improvement of medical students at learning at medical university by reforming the educational system in one, providing the logical transfer from theoretical learning stages to the professional activity and maximally approximating to real clinical environment conditions. The context approach encourages realization of this condition in the process of medical students' professional directionality development, integrating the system of scientific knowledge and the model of a specialist into the learning activity content, taking into account medical worker's profession peculiarities [26];

- synergetic approach forms cooperation among educational process' parties, new ideas about functioning mechanisms of self-organizing and self-developing systems, encourages self-realization, self-development of a future specialist's personality and is realized through his/her constant interaction with subjects of educational process [27].

An important component of this block is determination of pedagogical conditions of PrCFDM formation, necessary for achieving a result. The analysis of scientific sources and own pedagogical experience allowed to determine the following:

- formation of the future masters' of dentistry motivation to acquiring the praxeological competence through understanding the practical training importance for a dentist and self-development under conditions of fleeting changes and scientific achievements;

- formation of the educational environment with organizational, communicational and technological features, typical for the dentist's professional activity;

- elaboration of the dynamic scientific-methodical and methodical-technological base of the process of future masters' of dentistry professional training, using competence-oriented tasks, interdisciplinary integration;

- giving creative character to the educational process at the expanse of activation of students' scientificresearch work and their involvement by scientificpedagogical workers into profound studying of professional activity problems, searching for ways of their solving; doctors.

- teachers' readiness to $\mathrm{PrC}$ formation in future

- direction of the educational process content on consecutive formation of the system of practical abilities and skills in students, consisting of basic and professional knowledge.

Realization of pedagogical conditions needs correspondent content filling - renovation of traditional forms of educational process organization, especially: improvement of traditional, actualization of distant and introduction of innovative technologies; modern learning means, represented in the third, content-procedural block. In elucidates ways of providing the content filling of dentistry education by interdisciplinary integration of basic and professional subjects, improvement of methodological instruments (classroom work, projects, selfstudy, individual, distant forms; traditional, innovative, interactive methods; means of simulation, under clinic conditions, portfolio). The educational process is consid- 
ered as a totality of objective possibilities for creating a favorable educational environment, increasing the professional training efficiency and quality;

The forth, resulting-reflexive block reflects and fixes levels of future masters' of dentistry praxeological competence formation according to each of its structural components and is based on elaborated criteria (motivation, gnostic, activity, deontic, scientific-research, reflexive one) and correspondent indicators, providing their estimation by current monitoring and gives a possibility to ascertain an obtained educational result according to defined levels (minimal and sufficient).

The aforesaid blocks of the model give a possibility to take into account different influence factors (technogenic, sociogenic, professional-content, individual) of the educational process and to ascertain the obtained educational result, expressed in the correspondent PrFDM level. The main functioning principles of the presented model are defined as:

- correspondence of the final result to the set aim and tasks;

- technological character - practical realization of the model by introducing modern educational technologies, effectiveness of methodical instruments in PrCFDM formation;

- dynamics - provides development and selfdevelopment of the FDM professional training according to civilization changes in society;

- variability gives a possibility to change and to replace model components according to requirements and needs of the educational environment.

The aforesaid data allow to outline the importance of the developed model, especially:

- theoretical: to present the process of PrCFDM formation as an integral medical-pedagogical open system, able to change dynamically according to social needs, educational process aim, visualizes the interconnection among theoretical, content and procedural components of the studied process, encouraging the increase of an educational result level;

- practical: provides the proper functionality level of all components of the integral system of PrCFDM formation and timely introduction of necessary changes, appearing under the influence of internal and external factors under modern society dynamic conditions;

- creates a possibility for further development and interconnection between notions and phenomena of the studied process;

- provides realization of the competence approach at the FDM professional training as a base of the modern effective educational paradigm;

- encourages elimination of contradictions between rationality and spirituality due to PrCFDM motivational-value component formation.

It must be noted, that realization of the model is possible at both social consensus and educational process subjects' acknowledgement of necessary changes for elaborating the modern transparent logic system of future masters of dentistry professional training according to the National qualification frame, competence of the scientific-pedagogical staff of university.

So, the study testifies that the proposed system of PrCFDM formation is a way of forming a competitive specialist in the dentistry branch by modernizing the educational process in medical university, based on the competence educational paradigm, activation of learningcognitive activity and creative personal development. It gives a possibility to foresee and timely introduce necessary changes in the system of future masters of dentistry professional training, caused by both internal and external factors.

\section{Conclusions}

1. There has been theoretically substantiated the structural-functional model of future masters of dentistry praxeological competence formation that schematically reflects the educational process as the integral dynamic system, scientifically substantiated influence on which components provides progressive changes in quality increase of dental education.

2 . The schematic presentation of the studied process reflects conceptual and functional connections of basic components (notion, conceptual, procedural) that encourages aim achievement according to the goal and tasks, taking into account professional activity peculiarities.

\section{References}

1. Field, J. C., Cowpe, J. G., Walmsley, A. D. (2017). The Graduating European Dentist: A New Undergraduate Curriculum Framework. European Journal of Dental Education, 21, 2-10. doi: http://doi.org/10.1111/eje.12307

2. Ali, K., Slade, A., Kay, E., Zahra, D., Tredwin, C. (2017). Preparedness of undergraduate dental students in the United Kingdom: a national study. British Dental Journal, 222 (6), 472-477. doi: http://doi.org/10.1038/sj.bdj.2017.272

3. Kulbashna, Y. A., Nahirnyj, Y. P., Skrypnyk, I. L., Skibitska, O. O., Zakharova, V. O. (2020). Professional training of masters in dentistry in medical universities of ukraine and countries of the european union in terms of educational curricula and syllabi harmonization. Медична Освіта, 3, 118-125. doi: http://doi.org/10.11603/me.2414-5998.2020.3.11452

4. Kulbashna, Y., Skrypnyk, I., Zakharova, V. (2019). Portfolio as an instrument for future dentists' praxiological competence formation. The Pedagogical Process: Theory and Practice, 3-4, 67-76. doi: http://doi.org/10.28925/2078-1687.2019.3-4.6776

5. Kuzminskyi, A. I. (2012). Modeliuvannia osvitno-profesiinoi pidhotovky maibutnoho fakhivtsia v konteksti kompetentnisnoho pidkhodu. Vyshcha osvita Ukrainy, 1 (3), 29-42.

6. Titarenko, N. Yu. (2013). Formuvannia modelei profesiinykh kompetenoostei. Vyshcha osvita Ukrainy, 2, 88-91.

7. Kulbashna, Ya. A., Nahirnyi, Ya. P. (2014). Professional competence forming model of future dentist. Medical Education, $1,124-128$

8. Mruha, M. R. (2007). Strukturno-funktsionalna model profesiinoi kompetentnosti maibutnoho likaria yak osnova diahnostuvannia yoho fakhovykh yakostei. Kyiv, 21.

9. Stratehiia reformuvannia vyshchoi medychnoi osvity. Available at: https://moz.gov.ua/strategija-rozvitku-medichnoi-osviti 
10. Harzer, W., Tausche, E., Gedrange, T. (2015). Harmonisation of Dental Education in Europe - a survey about 15 years after visitation of dental schools participating in the DentEd project. European Journal of Dental Education, 21 (1), 22-27. doi: http://doi.org/10.1111/eje.12171

11. Reynolds, P. A., Eaton, K. A., Paganelli, C., Shanley, D. (2008). Nine years of DentEd - a global perspective on dental education. British Dental Journal, 205 (4), 199-204. doi: http://doi.org/10.1038/sj.bdj.2008.698

12. Cowpe, J., Plasschaert, A., Harzer, W., Vinkka-Puhakka, H., Walmsley, A. D. (2010). Profile and competences for the graduating European dentist - update 2009. European Journal of Dental Education, 14 (4), 193-202. doi: http://doi.org/10.1111/j.1600-0579.2009.00609.x

13. Cruess, S. R., Cruess, R. L., Steinert, Y. (2008). Role modelling - making the most of a powerful teaching strategy. BMJ, 336 (7646), 718-721. doi: http://doi.org/10.1136/bmj.39503.757847.be

14. Boiarchuk, N. (2013). Model formuvannia profesiinoi kompetentnosti maibutnikh ekonomistiv. Pedahohichni nauky, $1(57), 85-95$.

15. Vitvytska, S. S. (2006). Osnovy pedahohiky vyshchoi shkoly: pidruchnyk za modulno-reitynhovoiu systemoiu navchannia dlia studentiv mahistratury. Kyiv: Tsentr navchalnoi literatury, 416.

16. Mikheienko, O. I. (2015). Pidhotovka maibutnikh fakhivtsiv zi zdorovia liudyny do zastosuvannia zdoroviazmitsniuvalnykh tekhnolohii: teoretyko-metodychni aspekty. Sumy: Universytetska knyha, 316.

17. Demianenko, N. (2012). Innovatsiini pidkhody do pidhotovky pedahohichnykh kadriv. Pedahohichni nauky, 54, 46-54. Available at: http://nbuv.gov.ua/UJRN/pena_2012_54_11

18. Kulbashna, Y., Skrypnyk, I. (2020). Basic principles of praxeological competence formation in future masters of dentistry. ScienceRise: Pedagogical Education, 5 (38), 23-27. doi: http://doi.org/10.15587/2519-4984.2020.212893

19. Kulbashna, Y., Skrypnyk, I. (2020). The structure of master's in dentistry praxeological competence. Continuing Professional Education: Theory and Practice, 3, 71-77. doi: http://doi.org/10.28925/1609-8595.2020.3.8

20. Haluzevyi Standart vyshchoi osvity za spetsialnistiu «Stomatolohiia». Available at: https://docs.google.com/a/ bsmu.edu.ua/viewer?a=v\&pid=sites\&srcid=YnNtdS51ZHUudWF8ZWR1ZGVwdHxneDozNjE4NDA1NTgzNDc3Mzcx

21. Solodkov, V. T. (2011). Systemnyi pidkhid u vyshchii shkoli Navchalno-metodychnyi suprovid. knyha, 262.

22. Kurbatov, S. V. (2014). Fenomen universytetu v konteksti chasovykh ta prostorovykh vyklykakh. Sumy: Universytetska

23. Kyrian, T. I. (2017). The realization of personality oriented approach to learning and the personality formation of future nurses in high schools of Ukraine of the I-II accreditation levels (the end of XX - the beginning of XXI centuries). ScienceRise: Pedagogical Education, 1 (9), 24-27. doi: http://doi.org/10.15587/2519-4984.2017.91514

24. Melnychuk, I. M. (2012). Filosofsko-metodolohichni zasady profesiinoi pidhotovky maibutnikh fakhivtsiv sotsionomichnykh profesii. Medychna osvita, 3, 55-60.

25. Drach, I. I. (2015). Kompetentnisno oriientovani zavdannia yak vazhlyvyi chynnyk formuvannia profesiinoi kompetentnosti maibutnikh fakhivtsiv. Pedahohika formuvannia tvorchoi osobystosti u vyshchii i zahalnoosvitnii shkolakh, 44, $127-134$. Available at: http://nbuv.gov.ua/UJRN/Pfto_2015_44_19

26. Tykholaz, S. I. (2011). Kontekstnyi pidkhid do orhanizatsii navchalnoho protsesu yak umova rozvytku profesiinoi spriamovanosti studentiv medychnoho universytetu. Zbirnyk naukovykh prats Khmelnytskoho instytutu sotsialnykh tekhnolohii Universytetu Ukraina, 4, 165-169.

27. Ionova, O. M. (2011). Systemnyi ta synerhetychnyi pidkhody u pedahohichnykh doslidzhenniakh. Kharkiv: KhNPU im. H. S. Skovorody, 50.

Received date 15.12.2020

Accepted date 18.01.2020

Published date 30.01.2021

Iryna Skrypnyk, PhD, Associate Professor, Department of Orthodontics and Propedeutics of Prosthetic Dentistry, Bogomolets National Medical University, T. Shevchenko blvd., 13, Kyiv, Ukraine, 01601

E-mail: irynaskrypnyk@gmail.com

Yaroslava Kulbashna, Doctor of Pedagogical Sciences, PhD, Professor, Department of Surgical Dentistry and Oral and Maxillofacial Surgery, Bogomolets National Medical University, T. Shevchenko blvd., 13, Kyiv, Ukraine, 01601

E-mail: j.kulbashna@gmail.com 